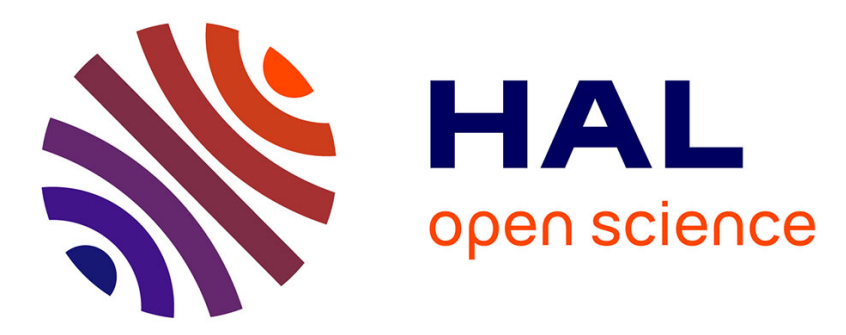

\title{
Economic impact of substituting solar photovoltaic electric production for tobacco farming
}

\author{
R. Krishnan, J.M. Pearce
}

\section{To cite this version:}

R. Krishnan, J.M. Pearce. Economic impact of substituting solar photovoltaic electric production for tobacco farming. Land Use Policy, 2018, 72, pp.503-509. 10.1016/j.landusepol.2018.01.010 . hal02111389

\section{HAL Id: hal-02111389 \\ https://hal.science/hal-02111389}

Submitted on 26 Apr 2019

HAL is a multi-disciplinary open access archive for the deposit and dissemination of scientific research documents, whether they are published or not. The documents may come from teaching and research institutions in France or abroad, or from public or private research centers.
L'archive ouverte pluridisciplinaire HAL, est destinée au dépôt et à la diffusion de documents scientifiques de niveau recherche, publiés ou non, émanant des établissements d'enseignement et de recherche français ou étrangers, des laboratoires publics ou privés. 


\title{
Economic Impact of Substituting Solar Photovoltaic Electric Production for Tobacco Farming
}

\author{
R. Krishnan ${ }^{1}$ and J.M. Pearce ${ }^{1,2,3^{*}}$
}

1. Department of Electrical \& Computer Engineering, Michigan Technological University, USA

2. Department of Materials Science \& Engineering, Michigan Technological University; USA

3. Department of Electronics and Nanoengineering, School of Electrical Engineering, Aalto

University, Espoo, Finland

\begin{abstract}
Solar photovoltaic (PV) technology represents a promising method to prevent dangerous global climate change, however full solar penetration demands substantial surface areas, possibly encroaching on arable land. To avoid repeating the mistakes of previous attempts to convert agricultural land to energy, arable land currently used for crops with known health hazards can be considered for conversion. Tobacco is the leading cause of avoidable death globally, and despite increasingly stringent controls on tobacco, economics provides an incentive to continue tobacco production. However, with the economics of PV ever improving, this study investigates the potential economic benefits of photovoltaic conversion of farms during tobacco's decline. This study analyzes key factors influencing conventional tobacco farming economics in the U.S. over a sensitivity of realistic future values. Then tobacco crop profit is compared to a sensitivity analysis covering the profits of solar PV farming on the same land. The results show that considering existing electric prices, escalation rates, and installed costs, PV farm substitution for tobacco farming makes economic sense in many U.S. cases already. In a case study of North Carolina, 30GW of PV power capacity was found to be economically viable on existing tobacco farms and if conversion took place over 2,000 premature deaths could be prevented from pollution reduction alone. This meets the State's peak summer loads. Land use policies are discussed to facilitate such land use conversions for the benefit of the economy, the environment and human health.

\section{Highlights}

* Large arable land conversion to solar PV farms to meet growing demand

*Decline in tobacco farming economics, potential arable land for PV farming

*Growing PV economics, sensitivity analysis on tobacco and PV farming key factors

*Calculation of tobacco and PV farming profit over 25 years with various sensitivities

* Many cases where PV farming is more profitable than tobacco farming
\end{abstract}

Keywords : solar photovoltaic; farming; agriculture; economic impact; tobacco

\section{Introduction}

Rapid growth in solar photovoltaic (PV) global production capacity [1], improvements in the solar energy conversion efficiency [2], and improved financing mechanisms [3] have all resulted in a radical decline in the price of solar electricity. This decline has resulted in a levelized cost of electricity that is now less expensive than traditional power in many regions [4]. Thus PV represents an economical method of providing for a growing fraction of society's electrical needs. This is important as the total global energy consumption has increased substantially and it is projected to reach 34,454 TWh by 2035 [5]. To prevent dangerous global climate change [6,7] and avoid externalities associated with other alternative energy sources [8], this power will need to be supplied by renewable energy sources [9-13].

To produce thousands of TWhs with solar electricity will involve the use of considerable land area [14]. Although much of this needed demand can be met with aggressive building integrated PV and rooftop PV [15-19], to meet all demands while avoiding the costs and negative externalities 
associated with conventional grid expansion [20-22], some arable land could be converted to PV farming.

Previous attempts to convert crop land to energy (e.g. ethanol production) have been blamed for rising global food prices and an expansion in hunger related suffering and mortality [23-27]. A more sensible and universally beneficial policy would first target energy production on arable land that currently grows crops with known health hazards and, consequently, shrinking economic markets. This would result in both a private and a social benefit. As the health-related dangers for tobacco [28-32] are well known to the medical community (tobacco use causes $\sim 6$ million deaths per year globally and represents the leading cause of preventable deaths [28]), it presents a suitable target crop. Despite substantial effort by public health officials to institute control policies [33-36], the U.S. Department of Health and Human Services considers the use of tobacco an epidemic [37] and controls have even been placed internationally such as the WHO's Global Treaty on Tobacco Control, which places broad restrictions on the sale, advertising, sponsorship, promotion, shipment, and taxation of tobacco products [38]. Despite these restrictions, economics provides an incentive to continue tobacco production. However, with the economics of PV ever improving, it may provide an economically beneficial path for tobacco farming decline.

This paper investigates the economic impact of substituting solar photovoltaic farms for tobacco farms in the U.S. First, a sensitivity analysis on key factors influencing conventional agricultural economics is performed over a sensitivity of realistic future values including: i) crop yield (pounds/acre); ii) crop price (\$/pound), iii) agricultural costs (\$/acre/year) and iv) the profits (\$/acre/year). Then the tobacco crop profit, is compared to a sensitivity analysis covering the profits of PV farming including: i) price per unit power installed (\$/ W), ii) solar energy production as a proxy for conversion efficiency ( $\mathrm{kWh} / \mathrm{acre})$, iii) electricity rates $(\$ / \mathrm{kWh})$ and iv) revenue earned per unit area (\$/acre). The tobacco estimates are generous as tobacco demand in north America is falling due to public health efforts. These values are then used to determine the potential profit for the farmers (\$/acre) for tobacco crop substitution with solar photovoltaic farming. Finally, a selection of policy mechanisms are explored to evaluate methods to facilitate the land use conversions from tobacco farming to solar electric production for the benefit of the economy, the environment and human health.

\section{Materials and Methods}

\subsection{Traditional Tobacco Agriculture Value Over 25 Years of Land Use}

A case study is performed for tobacco growth in North Carolina [39,40]. The yield ranged from 2,389 in 2009 to 2,148 pounds/acre in 2015. The decrease in yield from the year 2015 onwards is primarily due to the end of the Tobacco Transition Payment Program (also known as the tobacco buyout) in 2014, which saw federal government payments towards tobacco producers and tobacco quota holders come to an end [41-43]. This along with the reduced incentive for the intensive labor and complex farming techniques required for tobacco farming, caused by a decrease in demand due to the strict anti-smoking policies and tax regulations [44-46] lead to the decrease in the yield of tobacco. The price for tobacco was \$1.61/pound in 2013. Based on USDA National Agricultural Statistics Services the yield is assumed to increase $1.5 \%$ per year and the price to increase $1 \%$ per year for 25 years.

The profits $\left(\mathrm{P}_{\text {tob }}\right)$ [\$/acre/year] earned by a farmer from conventional tobacco agriculture is:

$$
\mathrm{P}_{\text {tob }}=\mathrm{Y} * \mathrm{C}-\mathrm{E}
$$

Where $\mathrm{Y}$ is the yield [pounds /acre/year], $\mathrm{C}$ is the crop price [US\$/pound] and $\mathrm{E}$ are the expenditures [US \$]. E is held constant at $\$ 4,000$ /acre following [47]. The cost of tobacco farming is extremely high in comparison to food crops due to high pre-harvesting variable \& harvest 
variable costs [47-50]. The values of profit per acre of tobacco farming are graphed as a function of time for the sensitivities.

\subsection{Solar Photovoltaic Farm Value Over 25 Years of Land Use}

By analyzing the land usage and requirements for solar PV farms in the United States of America, the acres of land used to produce solar power can be evaluated [MW/acre] [51]. The packing factors are taken from the worst case published scenario of $0.109 \mathrm{MW} /$ acre to the average NREL studied packing factor of $0.1266 \mathrm{MW} / \mathrm{acre}$ [51].

These packing factors are used to create a model one acre PV solar farm at the locations for the case study from Section 2.1. Solar Advisor Model (SAM) (v2015.1.30, 64 bit) is used to determine the energy output (MWh/year) for the above packing factors. Table 1 summarizes the values used and the resulting energy outputs, which are then used as inputs into the economic model described below.

Table 1. Optimal geometries for Jacksonville, NC with a fixed tilt of $31^{\circ}$ and $0^{\circ}$ azimuth. study.

\begin{tabular}{|l|l|l|l|l|}
\hline $\begin{array}{l}\text { Packing } \\
\text { Factor: } \\
\text { kW/acre }\end{array}$ & $\begin{array}{l}\text { Number of } \\
\text { Modules }\end{array}$ & $\begin{array}{l}\text { Area of } \\
\text { Modules } \\
\mathbf{m}^{2}\end{array}$ & $\begin{array}{l}\text { Shading } \\
\text { Loss }\end{array}$ & $\begin{array}{l}\text { Energy } \\
\text { Output } \\
\text { (MWh/year) }\end{array}$ \\
\hline 109 & 360 & 691.6 & $1.6 \%$ & 167.6 \\
\hline 126.6 & 420 & 806.8 & $1.6 \%$ & 187.4 \\
\hline
\end{tabular}

A sensitivity analysis is performed on the rates of 5,10, 15 and 20 cents/kWh, which envelope the ranges in the standard rates of electricity, using three historical electrical rate escalations of 1) $0.3 \%$ (from 2010), 2\% (2016 projected) and 5.7\% (from 2008) [52], representing the low, average and high cases, respectively. To be clear these electric rates are generic as they can represent either a displaced generation rate at the lower end (e.g. for a utility) up to a displaced residential consumer rate at the higher end (e.g. for a microgrid or PPA). Depending on the electricity market a decision maker is targeting, the appropriate rate in the range can be used for analysis as the sensitivity covers the entire range.

The levelized cost of electricity (LCOE) produced by the PV followed the calculation from Branker et al. [4]:

$$
L C O E=\frac{\sum_{t=0}^{T} \frac{I_{t}+O_{t}+M_{t}+F_{t}}{(1+r)^{t}}}{\sum_{t=0}^{T} \frac{E_{t}}{(1+r)^{t}}}=\frac{\sum_{t=0}^{T} \frac{I_{t}+O_{t}+M_{t}+F_{t}}{(1+r)^{t}}}{\sum_{t=0}^{T} \frac{S_{t}(1-d)^{t}}{(1+r)^{t}}}
$$

Where:

$\mathrm{T}=$ Life of the project (years)

$\mathrm{t}=$ year $\mathrm{t}$

$\mathrm{E}_{\mathrm{t}}=$ Energy produced for $\mathrm{t}[\mathrm{kWh}]$

$\mathrm{I}_{\mathrm{t}}=$ Initial investment/cost of the system including construction, installation, etc. [\$]

$\mathrm{M}_{\mathrm{t}}=$ Maintenance costs for $\mathrm{t}[\$]$ 
$\mathrm{O}_{\mathrm{t}}=$ Operation costs for $\mathrm{t}[\$]$

$\mathrm{F}_{\mathrm{t}}=$ Interest expenditures for $\mathrm{t}[\$]$

$\mathrm{S}_{\mathrm{t}}=$ Rated energy o/p per year. [kWh/year]

1-d= Degradation factor

$\mathrm{r}=$ discount rate.

The values for the PV LCOE parameters are lifetime $\mathrm{T}=25$ years, initial investment $\left(\mathrm{I}_{\mathrm{t}}\right)$ was given by $\mathrm{P}$ nominal times the cost per unit power was taken over a range : $\$ 0.80 / \mathrm{Wp}, \$ 1.00 / \mathrm{Wp}$, $\$ 1.50 / \mathrm{Wp}$ and $\$ 2.00 / \mathrm{Wp}$ [53], $\mathrm{M}_{\mathrm{t}}+\mathrm{O}_{\mathrm{t}}$ was set at $1.5 \%$ of $\mathrm{I}_{\mathrm{t}}$ and $\mathrm{d}$ was taken to be $0.5 \%$ [4]. The ranges of initial investment costs are taken to cover all possible scenarios.

The SAM is also is used to calculate the LCOE values for the case study location using the above assumed parameters. In addition, indirect costs like sales tax, land costs, engineering costs, grid connection costs were folded into the It and were not considered independently in SAM. The tax \& insurance rates along with salvage values have also not been considered. Finally, no incentives are considered.

The two packing factor cases are $109 \mathrm{~kW} /$ acre and $126.6 \mathrm{~kW} /$ acre respectively. $\mathrm{I}(\mathrm{t})$ is calculated by multiplying the cost per unit power ( $\$ / \mathrm{Wp}$ ) with the packing factor values. Table 2 tabulates the results of LCOE calculation using the above parameters.

Table 2: LCOE over 25 years for Jacksonville, NC

\begin{tabular}{|c|c|c|c|c|}
\hline $\begin{array}{c}\text { Cost per unit } \\
\text { power (\$W/) }\end{array}$ & $\begin{array}{c}\mathbf{I}(\mathbf{t}) \text { for 109 } \\
\mathbf{k W} / \text { acre packing } \\
\text { factor } \mathbf{( \$ )}\end{array}$ & $\begin{array}{c}\mathbf{I}(\mathbf{t}) \text { for 126.6 } \\
\mathbf{k W / a c r e ~ p a c k i n g} \\
\text { factor } \mathbf{( \$ )}\end{array}$ & $\begin{array}{c}\text { LCOE with } \\
\mathbf{1 0 9 k W / a c r e} \\
\text { packing factor } \\
\mathbf{( \$ / k W h )}\end{array}$ & $\begin{array}{c}\text { LCOE with } \\
\mathbf{1 2 6 . 6 k W / a c r e} \\
\text { packing factor } \\
\mathbf{( \$ / k W h )}\end{array}$ \\
\hline$\$ 0.80$ & 87,200 & 101,280 & 0.0940 & 0.0964 \\
\hline$\$ 1.00$ & 109,000 & 126,600 & 0.1119 & 0.1118 \\
\hline$\$ 1.50$ & 163,500 & 189,900 & 0.1544 & 0.1560 \\
\hline$\$ 2.00$ & 218,000 & 253,200 & 0.1901 & 0.2009 \\
\hline
\end{tabular}

The profits $\left(\mathrm{P}_{\mathrm{PV}}\right)$ [\$/acre/year] earned by a farmer from the PV farm are:

$$
\mathrm{P}_{\mathrm{PV}}=\mathrm{E}^{*}\left(\mathrm{r}_{\mathrm{e}}-\mathrm{LCOE}\right)
$$

Where $\mathrm{E}$ is the energy output [kWh/year], $\mathrm{r}_{\mathrm{e}}$ is the rate of electricity [ $\$ / \mathrm{kWh}$, and LCOE is given by equation (2).

\subsection{Comparison}

Finally the results of Section 2.1 and 2.2 are compared to find scenarios where conversion of tobacco crop land to solar photovoltaic production provides economic incentives for farmers. This data is plotted over an extrapolated 25 year time frame to obtain the net present value of investing in farm conversion.

\section{Results}

Profits (\$/acre/year) from tobacco farming using equation 1 and assuming a yield increasing $1.5 \% /$ year and the price increasing 1\%/year for 25 years is determined. It should be pointed out here that these are inherently conservative and thus optimistic assumptions for the price increases for tobacco given the large global efforts in the public health community to reduce tobacco demand. 
The sensitivity analysis on the effective rate with three escalations rates $(0.3 \%, 2.0 \%, 5.7 \%$ annually) on the bench mark electric rates of 5, 10, 15 and 20 cents/kWh is shown in Figure 1.

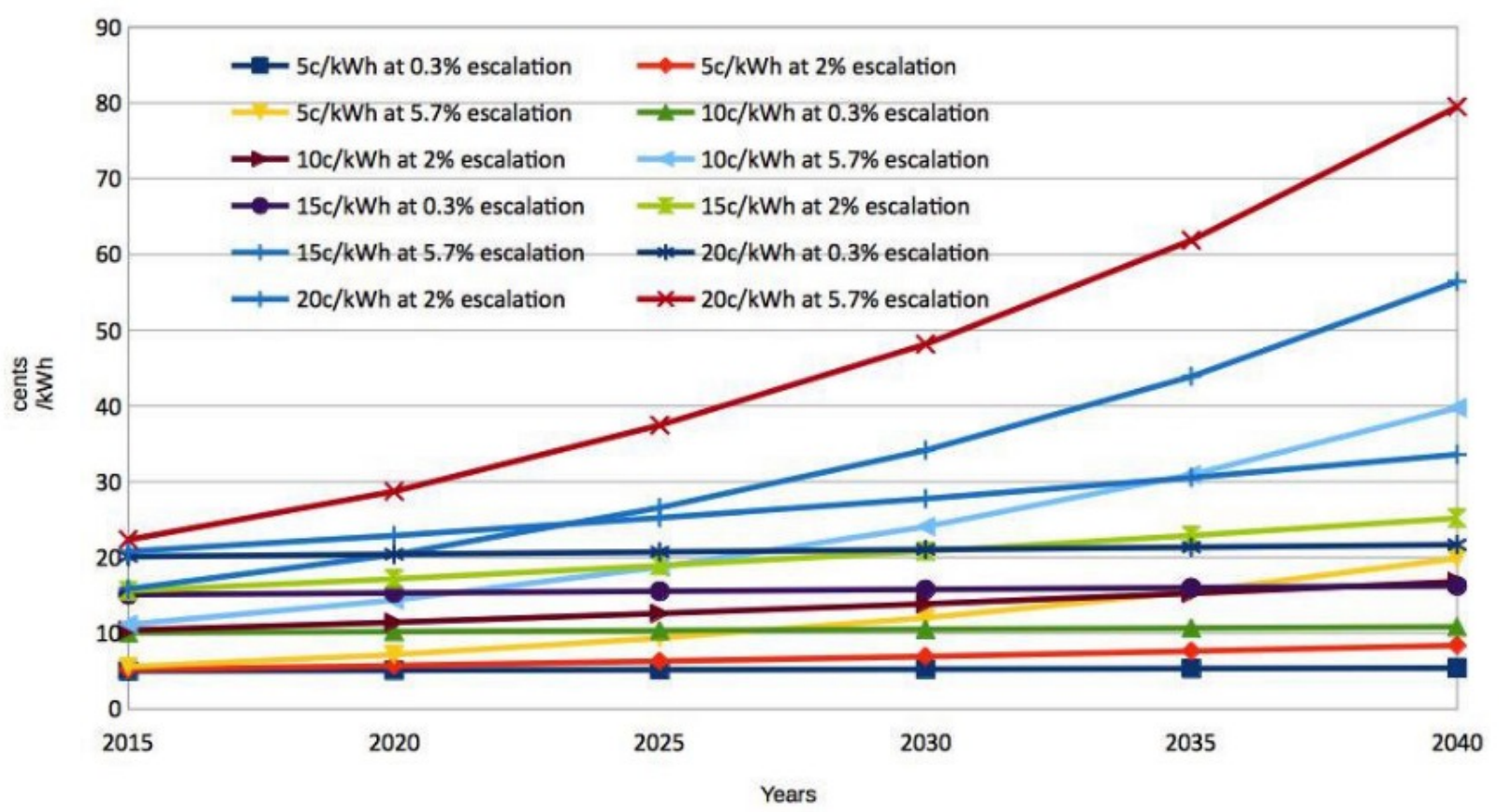

Figure 1: Sensitivity analysis on standard rates of 5, 10, 15 and 20 cents/kWh at escalation rates of $0.3,2.0$ and $5.7 \%$ per year respectively

In order to compare the profitability of PV farms with conventional farming the data and Fig. 1 are combined in equation 3 to generate profits shown in Figure 2 for case 1 packing factor of $109 \mathrm{~kW} /$ acre. In Figure 2, $\$ 0.80 / \mathrm{Wp}, \$ 1.00 / \mathrm{Wp}, \$ 1.50 / \mathrm{Wp}$ and $\$ 2.00 / \mathrm{Wp}$ cost for PV systems is compared to the profits from tobacco farming. Similarly, Figure 3 shows the profitability of PV farms with conventional farming the data for case 2 packing factor 126.6kW/acre. Negative values of PV profits indicate that the PV substitution were not economic alone and were omitted for Figure 2 and 3 for clarity. It should be pointed out that this is why for example in the case of $\$ 2.00 / \mathrm{Wp}$ at 10 cents/kWh and 15 cents/kWh at an increase rate of 5.7\%/year the values are shown far to the right on the x-axis as PV systems make economic sense only around the year 2020 and 2026, respectively.

As can be seen in Figure 2 and 3, at an escalation rate of 5.7\% per year, standard rates of 10, 15 and 20 cents/kWh, the PV systems prove to be more profitable than tobacco farming, when the cost per unit power is either $\$ 0.80$ or $\$ 1.00 / \mathrm{Wp}$ and in a few cases, even at $\$ 1.50 / \mathrm{W}$ and $\$ 2.00 / \mathrm{Wp}$. When the highest rate of 20 cents/kWh is considered, even with escalation rates of $0.3 \%$ and $2.0 \%$ per year, the profits obtained from PV systems installed for $\$ 1.00 / \mathrm{Wp}$ or below are higher than the profits from tobacco farming. Since the rate of 5 cents/kWh at all $\$ 1.00 / W p$ cases generate negative results of profits, they are not displayed. 


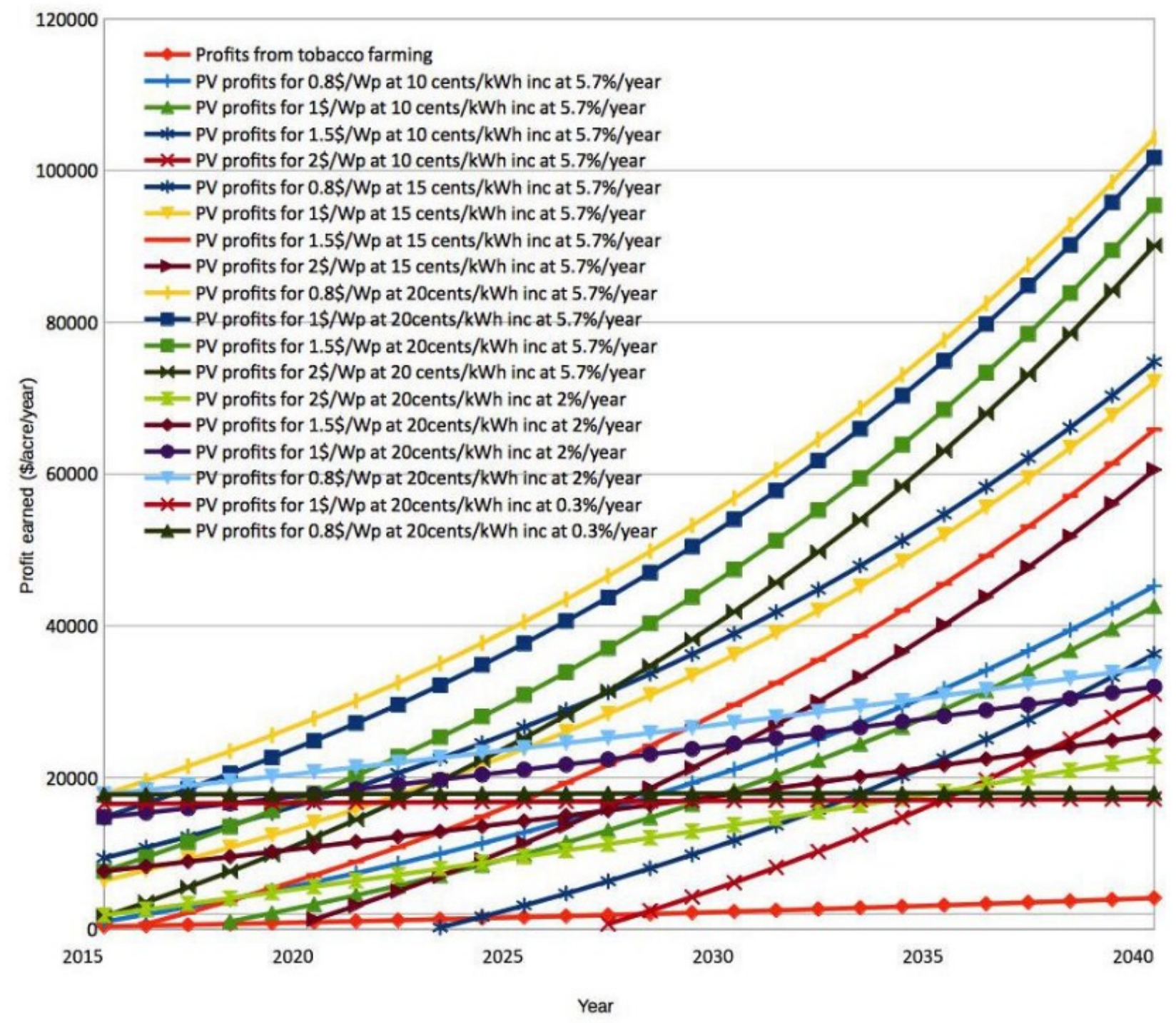

Figure 2: Profits earned from PV systems for the case 1 packing factor of $109 \mathrm{~kW} /$ acre using equation 3 for $\$ 0.80 / \mathrm{Wp}, \$ 1.00 / \mathrm{Wp}, \$ 1.50 / \mathrm{Wp}$ and $\$ 2.00 / \mathrm{Wp}$ cost per unit power against profits from tobacco farming 


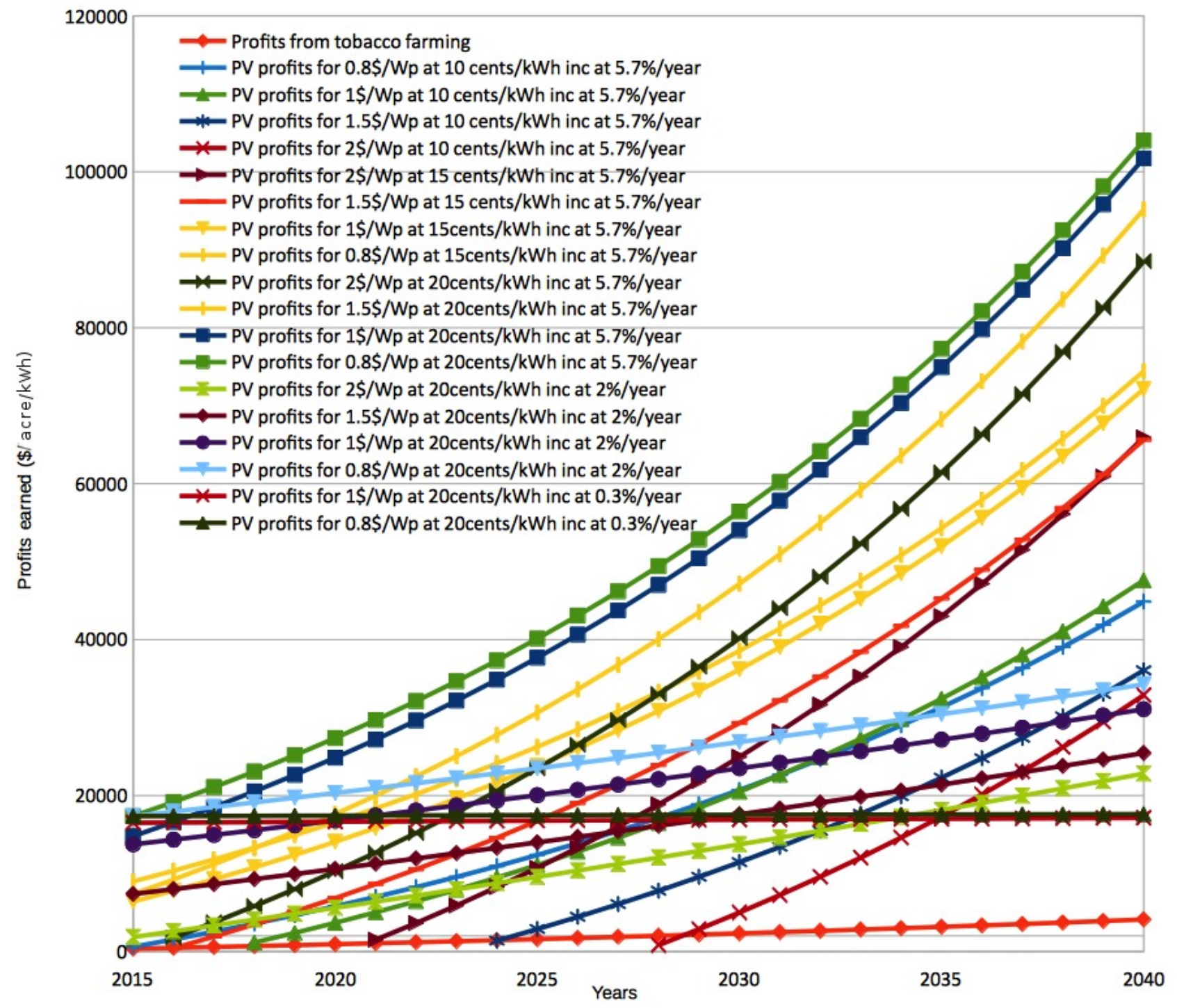

Figure 3: Profits earned from PV systems for the case 2 packing factor of $126.6 \mathrm{~kW} / \mathrm{acre}$ using equation 3 for $\$ 0.80 / \mathrm{Wp}, \$ 1.00 / \mathrm{Wp}, \$ 1.50 / \mathrm{Wp}$ and $\$ 2.00 / \mathrm{Wp}$ against profits from tobacco farming

\section{Discussion}

\subsection{Economic Impact}

As can be clearly seen from Figures 2 and 3, PV farming makes more economic sense than tobacco farming when the generated electricity is sold at a low of 10 cents $/ \mathrm{kWh}$ at $5.7 \%$ escalation rate per year at $\$ 2.00 / \mathrm{W}$ and below cost price, as well as at a high of $20 \mathrm{cents} / \mathrm{kWh}$ at $0.3 \%$ escalation rate per year at $\$ 1.00 / \mathrm{W}$ and below price per unit power. Considering the former, with the current average USA residential and commercial rates rated around 12 and 10 cents/kWh, respectively [52] escalating at a projected rate of $4 \%$ annually [52], PV farm substitution for tobacco farming makes economic sense in many cases already. This is particularly the case if the PV farm can arrange a power purchase agreement (PPA) with consumers or utilities.

The rapid decreasing installed costs of PV [54-56] as well as the government incentives offered for installing PV systems in most regions of the United States [57,58] has built a very strong case for 
investing in large scale PV systems. With some regions in United States already averaging electricity prices of 18-23 cents/kWh [52] (e.g. Houghton, MI; Connecticut; Alaska) PV farming may already make financial sense if PPAs or microgrids can be arranged. Utility PV systems are already being installed in in the U.S. for less than \$1.00/W [56].

For example, in North Carolina itself, which is used in the PV simulations, the average residential rate is $\$ 0.11 / \mathrm{kWh}$ [52]. The results show that electricity generated from solar farms with realistic installation costs (e.g. $\$ 2.00 / \mathrm{W}$ ) there is potential profit to be made for tobacco farm conversion to solar farms if agreements can be made with North Carolina's electric customers. This year (2017) the utility-scale solar systems were priced at an average of $\$ 0.99 / \mathrm{W}$ to $\$ 1.08 / \mathrm{W}$ [59], so this criteria is now readily met. With an average of 232,000 acres used for tobacco farming in North Carolina [60], and an average packing factor of $0.1266 \mathrm{MW} /$ acre used in the study would produce an approximately $30 \mathrm{GW}$ of solar power. Interestingly, the net summer capacity for North Carolina is 30.068GW and the state generates 125,936,293 MWh [61]. Although the peak power rating is similar to the that needed in North Carolina, it should be pointed out that the capacity factor for solar is not $100 \%$ so could not supply all of North Carolinas electrical needs with tobacco farm area alone unless aggressive efficiency measures were put in place. However, to put this significant amount of power value in perspective, consider that the Solar Energy Industries Association expects the entire U.S. PV installed capacity to only reach 40GW in 2017 [62].

\subsection{Health Impacts}

It is important to note if the elimination of tobacco farming in the U.S. coinciding with a smoke free nation, more than 480,000 deaths per year in the United States from cigarette smoking and nearly 42,000 deaths resulting from secondhand smoke exposure would be prevented [63]. This represents a total of over half a million premature deaths prevented in the U.S. directly. In addition as the PV generated electricity would off-set less economic coal-fired electricity additional lives would be saved. A recent study found that if all coal-fired electricity production were eliminated by PV in the U.S. approximately 52,000 premature deaths would be prevented [64]. To accomplish this, $755 \mathrm{GW}$ of U.S. PV installations are needed [64], so the percent of this total can be used to determine the additional lives $\left(\mathrm{L}_{\mathrm{A}}\right)$ saved following:

$$
L_{A}=\left(\frac{P}{755 G W}\right) \times 52,000 \text { (lives) }
$$

where $\mathrm{P}$ is the power in GW for a given location. So for example, using equation 3, the $30 \mathrm{GW}$ of potential PV that would replace North Carolina's tobacco fields would save over another 2,000 lives per year. As the primary and secondary health benefits of replacing tobacco with PV production are overwhelming and the economics are positive land use policies to encourage this transition are warranted.

\subsection{Land Use Policy Impacts}

The results found in this techno-economic analysis provide a strong case for a method to convert tobacco farms to economically more productive uses in general, however, there are practical limitations that any tobacco farm would need to overcome and appropriate land use policy could aid in the transition. The primary limitation is the capital cost of the PV system (e.g. a $10 \mathrm{MW}$ PV farm priced at $\$ 1.00 / \mathrm{W}$ costs $\$ 10$ million dollars) and tobacco farmers may not have either the capital or access to loans of that magnitude to enable the investment. There are several policy mechanisms that could be used to increase the rate of conversion by assisting the access to capital for the investment. These policies could expand past conventional land use policies such as zoning and take advantage of policies normally confined to the manufacturing sector. These policies can be enacted by the federal government to overall strengthen the U.S. economy while preventing more than $100 \mathrm{X}$ as many premature deaths every year than $9 / 11$, the worst terrorist attack in U.S. history. 
In the case where federal leadership is not available individual tobacco-producing states like North Carolina can implement the following policies at the state level. The policy suggestions are listed in order of increasing impact: (i) an income tax holiday, (ii) loan guarantee for construction, (iii) partially subsidize construction, and (iv) full construction subsidy. Each of these policy recommendations will be evaluated in turn. It should be noted that these are all positive reinforcing policies that only provide extra incentives to increase income for current land owners. Similarly, policies meant to increase the rate of tobacco farming decline (disincentive policies) could be used such as (v) tax land if it is used for tobacco farming, (vi) rezoning to separate tobacco farming into a special class and then eliminate it or (vii) simply ban all tobacco farming.

As Geoghegan has pointed out there are many approaches to incentivizing desirable land use such as open space [65] and the income tax code can effect land use patterns. By offering farmers an income tax holiday at the federal or state level for conversion of tobacco farms to PV farms the economic profitability outlined in this paper are made stronger and provide a clear policy support to land owners. This, however, would result in the tax income loss from the existing tobacco production without replacing it with the more lucrative solar electricity value generation. For a revenue neutral approach, the increased taxes the government would acquire (or some percentage of them) again could be passed back to the converting land owners.

Second, similar to work land use policy related to the financing of urban regeneration [66] governments can become involved to help farmers obtain the necessary financing to undergo the transition. The structuring of finance in urban regeneration projects [66] or in a tobacco to photovoltaic farm conversion is seen as crucial in determining the viability of the scheme, as it enables a form of offsetting risk and in achieving an adequate return. In this case, by guaranteeing the project, the government effectively reduces the cost of capital as well as potentially making the entire project viable as the exposure of the lenders is greatly reduced. Again, this policy could be applied on a sliding scale from a percentage that enables the loan to take place (based on the financial situation of the land owner) all the way to a 100\% loan guarantee from the government. A mechanism to reduce risk for all parties is a power purchase agreements (PPA), which guarantees a purchase price per kWh over an extended time period $[3,67,68]$. With a PPA in place, risks for the government with $100 \%$ loan guarantees would be substantially reduced [68].

An even more aggressive method of creating preferred land use is direct subsidies [69], which is well-established practice to meet desired land use goals. As applied here, the federal or state government could (iii) partially subsidize construction, and (iv) fully subsidize the PV farm construction. As shown above this would not be a direct loss of the subsidized amount as the government would directly benefit from increased tax revenues from a) the taxing of the construction including materials and labor, and the taxing of the value from the solar electricity, which is greater than the tobacco sales. However, there would also be indirect revenue from solar farm employees and initial construction workers spending some of their earning in the local economy as well as increased economic activity due to the reduction in mortality and morbidity from reduced tobacco sales. Future work is needed to quantify these benefits.

These last three recommendations ( $\mathrm{v}$-vii) could be coupled to (i-iv) to prevent economic hardship for tobacco farm owners. The aggressiveness of the land use policy should be determined by the economic necessity. For example, in some regions tobacco farmers may only need a small financial incentive (e.g. policy i) to pull them into conversion, whereas others may not have the access to loans and policy ii is more appropriate. Although iii and iv at first appear radical, considering the number of saved American lives per year, the investments are modest compared to other health-related policy investments or the multiple trillions of dollars spent to reduce premature deaths from terrorism [70].

\section{Limitations and Future Work}


Previous work in Canada on solar farm location optimization has suggested selecting the candidates for new solar PV farms based on meeting three criteria: (1) located within $2 \mathrm{~km}$ from the transmission lines, (2) having an area of at least 100 acres and (3) a slope of no more than 4\% [71]. The degree to which these criteria can be relaxed in the U.S. due to improved solar flux in some locations and the shifting PV costs is left for future work. In addition to the purely technical limitations for a given location in order to make a farm conversion viable there must be a means of selling the solar generated electricity. Again the specifics based on regulations, incentives and utility rules vary widely on state and jurisdiction and future work is needed in this area. One potential mechanism with significant promise to benefit all parties is the PPA noted above[3,68]. These prices can be flat or escalate at a known rate over time, which provides energy price security to buyers, whether groups of individuals, companies or utilities.

Finally it should be pointed out that this study has inherent limitations. It did not take into account the negative externalities of PV. Although these certainly exist [72] and authors have called for example, producer responsibility [73] for PV, the solar-related externalizations and resultant morbidity and mortality is orders of magnitude less than the fossil fuels PV replaces [72]. In addition, this analysis does not provide a detailed economic analysis of the behavior of agricultural farming in the near future. For example, in the study, the yield and price of crops are assumed to escalate every year keeping into account the constant expenses per year. This was done both to remain conservative as pointed out earlier, but also limitations in the ability to predict future markets. Further research in this area is needed, particularly in the case of tobacco as there is significant evidence that the production is rapidly declining in the U.S. and may continue in the future as the demand is reduced [74-76]. As was pointed out above, because of the large input costs of tobacco farming compared to other crops as demand decreases the yield tends to decrease, which again would have the effect of understating the magnitude of the potential benefits from converting tobacco farms to PV production. In addition, other crops could also provide tobacco farmers with increased profits while reducing premature deaths from smoking. In the energy field, in addition to PV discussed here, biofuel crops [77] could also be considered in future work. Finally, future work could build upon this study to analyze state/government incentives while calculating LCOE, use of different types of PV systems (e.g. low concentration [78] and tracking systems [79]) and the economic study of agriculture farming in the near future.

\section{Conclusions}

With the ever increasing importance of meeting the growing electricity demand with sustainable energy, this study analyzed the economic value of converting arable land currently used for tobacco production to photovoltaic farms. The results showed that with electricity generated from solar farms with realistic installation costs (e.g. \$2.00/W) there is potential profit to be made for tobacco farm conversion. If all of the tobacco farms in North Carolina were converted to solar farms there is a potential solar generating capacity of $30 \mathrm{GW}$, which is equivalent to the States peak summer load. This North Carolina acreage of tobacco farming land, which occupies more than 200,000 acres, is currently considered a threat to global health by the World Health Organization, the U.S. Department of Health and Human Services, the Centers for Disease Control and Prevention, the National Center for Chronic Disease Prevention and Health Promotion, Office on Smoking and Health. If converted the same land would become an environmental and health related global asset while generating more profit for the land owners.

\section{References}

1. Gaëtan Masson (iCARES consulting), Sinead Orlandi, Manoel Rekinger, European Photovoltaic Industry Association "Global Market outlook for Photovoltaics from 20142018”, 2014. 
2. M. A. Green, K. Emery, Y. Hishikawa, W. Warta, and E. D. Dunlop, "Solar cell efficiency tables (Version 45): Solar cell efficiency tables," Progress in Photovoltaics: Research and Applications, vol. 23, no. 1, pp. 1-9, Jan. 2015.

3. T. Alafita and J.M. Pearce,"Securitization of Residential Solar Photovoltaic Assets: Costs, Risks and Uncertainty", 2014.

4. K. Branker, M. J.M. Pathak, J. M. Pearce, "A Review of Solar Photovoltaic Levelized Cost of Electricity", Renewable \& Sustainable Energy Reviews 15, pp.4470-4482 (2011).

5. World Nuclear Association "World Energy Needs and Nuclear Power", 2015.

6. R. H. Moss, J. A. Edmonds, K. A. Hibbard, M. R. Manning, S. K. Rose, D. P. van Vuuren, T. R. Carter, S. Emori, M. Kainuma, T. Kram, G. A. Meehl, J. F. B. Mitchell, N.

Nakicenovic, K. Riahi, S. J. Smith, R. J. Stouffer, A. M. Thomson, J. P. Weyant, and T. J. Wilbanks, "The next generation of scenarios for climate change research and assessment," Nature, vol. 463, no. 7282, pp. 747-756, Feb. 2010.

7. International Energy Agency "Energy and Climate Change" World Energy Outlook Special Report, 2015

8. J. M. Pearce, "Thermodynamic limitations to nuclear energy deployment as a greenhouse gas mitigation technology," International Journal of Nuclear Governance, Economy and Ecology, vol. 2, no. 1, pp. 113-130, 2008.

9. Joshua Pearce, "Photovoltaics-A Path to Sustainable Futures", Futures 34(7), 663-674, 2002.

10. International Energy Agency "World Energy Outlook 2012 Executive Summary"

11. MEETING THE ENERGY CHALLENGES OF THE FUURE A GUIDE FOR POLICYMAKERS. Denver, Colorado: The National Conference of State Legislatures, 2010.

12. G. S. R. First, "Renewable Energy Policy Network for the 21st Century," 2009.

13. M. Z. Jacobson and M. A. Delucchi, "Providing all global energy with wind, water, and solar power, Part I: Technologies, energy resources, quantities and areas of infrastructure, and materials," Energy Policy, vol. 39, no. 3, pp. 1154-1169, Mar. 2011.

14. Zweibel, K., Mason, J., \& Fthenakis, V. (2008). A solar grand plan. Scientific American, $298(1), 2008$.

15. L.K. Wiginton, H. T. Nguyen, J.M. Pearce, "Quantifying rooftop solar photovoltaic potential for regional renewable energy policy", Computers, Environment and Urban Systems 34, (2010) pp. 345-357.

16. H.T. Nguyen and J.M. Pearce, "Automated Quantification of Solar Photovoltaic Potential in Cities" International Review for Spatial Planning and Sustainable Development 1(1), 57-70 (2013).

17. Ha T. Nguyen, Joshua M. Pearce, Rob Harrap, and Gerald Barber, "The Application of LiDAR to Assessment of Rooftop Solar Photovoltaic Deployment Potential on a Municipal District Unit", Sensors, 12, pp. 4534-4558 (2012).

18. R. Duke, R. Williams, and A. Payne, "Accelerating residential PV expansion: demand analysis for competitive electricity markets," Energy Policy, vol. 33, no. 15, pp. 1912-1929, Oct. 2005.

19. W. Hoffmann, "PV solar electricity industry: Market growth and perspective," Solar Energy Materials and Solar Cells, vol. 90, no. 18-19, pp. 3285-3311, Nov. 2006.

20. Fouillet A, Rey G, Laurent F, Pavillon G, Bellec S, Guihenneuc-Jouyaux C, Clavel J, Jougla E, Hémon D. Excess mortality related to the August 2003 heat wave in France. International Archives of Occupational and Environmental Health, vol. 80, no. 1. 2006;1624.

21. Vine E. Adaptation of California's electricity sector to climate change. Climatic Change, vol. 111, no. 1. 2012;75-99. 
22. Klinenberg E. Are You Ready for the Next Disaster?. New York Times Magazine, 2008.

23. Lester R.Brown "Why Ethanol Production Will Drive World Food Prices Even Higher in 2008”, 2008.

24. Lagi, M., Bar-Yam, Y., Bertrand, K. Z., \& Bar-Yam, Y. 2012:UPDATE February 2012-The Food Crises: Predictive validation of a quantitative model of food prices including speculators and ethanol conversion. arXiv preprint arXiv:1203.1313, 2012.

25. Albino, D. K., Bertrand, K. Z., \& Bar-Yam, Y. (2012): Food for fuel: The price of ethanol. arXiv preprint arXiv:1210.6080, 2012.

26. J. Fargione, J. Hill, D. Tilman, S. Polasky, and P. Hawthorne, "Land Clearing and the Biofuel Carbon Debt," Science, vol. 319, no. 5867, pp. 1235-1238, Feb. 2008.

27. Ralph Heimlich,R. A. et al. , "Use of U.S. Croplands for Biofuels Increases Greenhouse Gases Through Emissions from Land-Use Change,"Science 29 February 2008: Vol. 319 no. 5867 pp. 1238-1240 DOI: 10.1126/science.1151861

28. World Health Organization. WHO report on the global tobacco epidemic, 2011: warning about the dangers of tobacco, Geneva, Switzerland: World Health Organization; 2011.

29. World Health Organization. WHO report on the global tobacco epidemic, 2013: enforcing bans on tobacco advertising, promotion and sponsorship. Geneva, Switzerland: World Health Organization; 2013.

30. Barendregt JJ, Bonneux L, van der Maas PJ. The health care costs of smoking. N Engl J Med 1997;337(15):1052-57, 1997.

31. Murray CJ, Lopez AD. Global mortality, disability, and the contribution of risk factors: Global Burden of Disease Study. Lancet 1997;349:9063:1436-42, 1997.

32. Peto R, Lopez A. The future worldwide health effects of current smoking patterns. Tobacco and Public Health: Science and Policy, 2004;281-6.

33. Jha P. Curbing the Epidemic: Governments and the Economics of Tobacco Control. Herndon, VA: World Bank Publications; 1999.

34. Fichtenberg CM, Glantz SA. Association of the California Tobacco Control Program with declines in cigarette consumption and mortality from heart disease. N Engl J Med 2000;343(24), 1772-77.

35. Wakefield M, Durkin S, Spittal M, et al. Impact of tobacco control policies and mass media campaigns on monthly adult smoking prevalence. Am J Pub Health 2008; 98(8):1443.

36. Farrelly MC, Pechacek TF, Thomas, KY, Nelson D. The impact of tobacco control programs on adult smoking. Am J Pub Health 2008;98:2:304.

37. US Department of Health and Human Services. Ending the Tobacco Epidemic: A Tobacco Control Strategic Action Plan for the US Department of Health and Human.

38. World Health Organization. WHO Framework Convention on Tobacco Control, 2003.

39. North Carolina Department of Agriculture \& Consumer Services, 2012

40. United States Department of Agriculture National Agricultural Statistics Service

41. Blake Brown, North Carolina State University' "The End of Tobacco Transition Payment Program”, November 2013.

42. United States Department of Agriculture "Tobacco Transition Payment Program Fact Sheet" October 2009.

43. Guido van der Hoeven, T. Michael Till "Tobacco Buyout Issues: Inherited or Gifted Tobacco Quota Buyout Installment Contracts”, 2009

44. Jasper Womach "U.S. Tobacco Production, Consumption, and Export Trends", June 2003. Agriculture Policy Specialist, Resources, Science, and Industry Division.

45. L. Liang, F. J. Chaloupka, and K. Ierulli, "6. Measuring the Impact of Tobacco on State Economies," Evaluating ASSIST, p. 163, 2006

46. Diane Huntrods, AgMRC, Iowa State University “Tobacco Profile”, December 2012. 
47. NETAFIM USA “Tobacco Production Manual”, May 2013.

48. Eric Eberly, Extension Agent, Farm Business Management "Flue-cured Tobacco Budget Information", 2008.

49. L. Foreman, Tobacco Production Costs and Returns in 2004. US Department of Agriculture, Economic Research Service, 2006.

50. T. David Reed, Charles S. Johnson, Paul J. Semtner, Carol A. Wilkinson "2012 Flue-Cured tobacco production guide", 2012.

51. S. Ong, C. Campbell, P. Denholm, R. Margolis, and G. Heath, "Land-use requirements for solar power plants in the United States," Retrieved December, vol. 10, p. 2014, 2013.

52. eia Independent Statistics \& Analysis U.S Energy Information Administration "Short-term energy outlook", March 10,2015.

53. International Energy Agency “Technology Roadmap Solar Photovoltaic Energy 2014 edition”, September 2014.

54. David Feldman,Galen Barbose, Robert Margolis, Ted James, Samantha Weaver, NaïmDarghouth, Ran Fu, Carolyn Davidson, Sam Booth and Ryan Wiser "Historical, Recent, and Near Term Projections 2014 Edition” ,Sunshot U.S. Department of Energy, September 2014.

55. IRENA "Renewable Energy Technologies: Cost Analysis Series Solar Photovoltaics" Volume 1, Issue 4/5, June 2012.

56. Solar Energy Industries Association "Solar Industry Data” 2014.

57. Alan Goodrich, Ted James and Michael Woodhouse, "Residential, Commercial and Utility Scale Photovoltaic(PV) System Prices in the United States: Current Drivers and CostReduction Opportunities" National Renewable Energy Laboratory, Golden, CO, Tech. Rep. NREL/TP-6A20-53347, February 2012

58. C. Davidson, T. L. James, R. M. Margolis, R. Fu, and D. J. Feldman, US Residential Photovoltaic (PV) Systems Prices, Q4 2013 Benchmarks: Cash Purchase, Fair Market Value, and Prepaid Lease Transaction Prices. National Renewable Energy Laboratory, 2014.

59. Walton, R. Report: Utility-scale solar prices drop below \$1/watt for first time. Utility Dive. June 12, 2017. Available: http://www.utilitydive.com/news/report-utility-scale-solar-pricesdrop-below-1watt-for-first-time/444738/ (visited July 12, 2017).

60. North Carolina State University College of Agriculture and Life Sciences "2015 guide Fluecured Tobacco", 2015.

61. U.S. EIA. 2013. North Carolina Electricity Profile 2013. https://www.eia.gov/electricity/state/northcarolina/

62. Kenning T. US solar installed capacity to reach 40GW by 2017. PV Tech. <http://www.pvtech.org/news/us_solar_installed_capacity_to_reach_40gw_by_2017 > (accessed on June 1, 2015).

63. U.S. Department of Health and Human Services. The Health Consequences of Smoking-50 Years of Progress: A Report of the Surgeon General. Atlanta: U.S. Department of Health and Human Services, Centers for Disease Control and Prevention, National Center for Chronic Disease Prevention and Health Promotion, Office on Smoking and Health, 2014.

64. Prehoda, E.W. and Pearce, J.M., 2017. Potential lives saved by replacing coal with solar photovoltaic electricity production in the US. Renewable and Sustainable Energy Reviews, 80, pp.710-715.

65. Geoghegan, J. 2002. The value of open spaces in residential land use. Land Use Policy, 19(1), 91-98. 
66. Adair, A., Berry, J., McGreal, S., Deddis, B., \& Hirst, S. 2000. The financing of urban regeneration. Land Use Policy, 17(2), 147-156.

67. Davidson, C., Steinberg, D., \& Margolis, R. 2015. Exploring the market for third-partyowned residential photovoltaic systems: insights from lease and power-purchase agreement contract structures and costs in California. Environmental Research Letters, 10(2), 024006.

68. Kollins, K., Speer, B., \& Cory, K. 2009. Solar PV project financing: Regulatory and legislative challenges for third-party PPA system owners (No. NREL/TP-6A2-46723). National Renewable Energy Laboratory (NREL), Golden, CO..

69. van Meijl, H., Van Rheenen, T., Tabeau, A., \& Eickhout, B. (2006). The impact of different policy environments on agricultural land use in Europe. Agriculture, Ecosystems \& Environment, 114(1), 21-38.

70. Carter, S. and Cox, A., 2011. One 9/11 Tally: \$3.3 Trillion. The New York Times, 8. Available: http://www.nytimes.com/interactive/2011/09/08/us/sept-11-reckoning/cost-graphic.html? $\mathrm{r}=0$

71. H.T. Nguyen and J.M. Pearce, "Estimating Potential Photovoltaic Yield with r.sun and the Open Source Geographical Resources Analysis Support System” Solar Energy 84, pp. 831843, 2010.

72. Fthenakis, V. and Alsema, E., 2006. Photovoltaics energy payback times, greenhouse gas emissions and external costs: 2004-early 2005 status. Progress in Photovoltaics: research and applications, 14(3), pp.275-280.

73. McDonald, N.C. and Pearce, J.M., 2010. Producer responsibility and recycling solar photovoltaic modules. Energy Policy, 38(11), pp.7041-7047.

74. Jasper Womach "U.S. Tobacco Production, Consumption, and Export Trends", 2003.

75. Center for Disease Control \& Prevention (CDC) "Economic Facts About U.S. Tobacco Production and Use", 2013.

76. North Carolina Cooperative Extension Service "Guide to Flue-cured tobacco" 2013.

77. Calvert, K., and W. Mabee. "More solar farms or more bioenergy crops? Mapping and assessing potential land-use conflicts among renewable energy technologies in eastern Ontario, Canada." Applied Geography 56 (2015): 209-221.

78. Andrews, Rob W., Andrew Pollard, and Joshua M. Pearce. "Photovoltaic System Performance Enhancement With Non-Tracking Planar Concentrators: Experimental Results and Bi-Directional Reflectance Function (BDRF) Based Modelling." IEEE Journal of Photovoltaics 5, no. 6 (2015): 1626-1635.

79. de Simón-Martín, M., Alonso-Tristán, C., \& Díez-Mediavilla, M. (2014). Performance Indicators for Sun-Tracking Systems: A Case Study in Spain. Energy and Power Engineering, 6(09), 292. 